\title{
The effect of Sharia bank knowledge, promotion, and facilities on savings decisions at Sharia banks with savings interest as mediation variables
}

\author{
Oriesta Dhea Budi Utamy ${ }^{1}$, Ratieh Widhiastuti ${ }^{2}$ \\ 1,2Universitas Negeri Semarang, Indonesia
}

\begin{abstract}
Purpose-The purpose of this study is to explain the effect of Sharia bank knowledge, promotion, and facility on saving decisions in Shariah Bank both directly and through saving interest.

Method - The population in this study is the students of Sharia Banking department at Islamic Business and Economics Faculty of IAIN Purwokerto Batch 2016/2017 of 106 students. All populations in this study were used as the sample. The technique of data collection in this study used questionnaires. Techniques of data analysis used descriptive statistic analysis and path analysis.

Result - The results showed that Sharia bank knowledge, promotion, and facility give a positive and significant effect on saving decisions in Sharia Bank. Saving interest can mediate Sharia bank knowledge, promotion, and facility on saving decision in Sharia Bank.

Implication - Suggestion from this study are expected that Sharia Bank can fix the facility and improve promotions so that the customer candidate can know what kind of product offered so that saving interest and saving decision in Sharia Bank can be improved.
\end{abstract}

Originality-This study adds Islamic bank knowledge and saving interest variable as the intervening variable.

Keywords: Sharia bank; knowledge; promotion; facility; saving Interest; saving decision

\footnotetext{
2 Ratieh Widhiastuti, ratieh.widhiastuti@mail.unnes.ac.id, Universitas Negeri Semarang, Sekaran, Kec. Gn. Pati, Kota Semarang, Jawa Tengah 50229, Indonesia
} 


\section{Introduction}

The economic activity of a country is always related to the traffic of money payments, where the banking industry has a very strategic role, namely as the JIEMB $\mid 2$ vein of the economic system (Pertiwi \& Ritonga, 2010). According to Law No. 10 of 1998 concerning banking, based on its operational principles, banks are divided into two, namely conventional banks and Islamic banks. Islamic banks appear as an alternative for people who need a banking system that provides banking/financial services that are healthy and meet Islamic principles. The culture built by Islamic banking is to build a profit and loss sharing system that is the basic principle of Islamic banking operations (Yupitri \& Sari, 2012).

Along with the development of Islamic banking in Indonesia, the Islamic economy in Indonesia also continues to grow and is very rapid, this development is seen based on the number of banks, the number of branch offices and total assets in the past four years. Based on Sharia banking statistics released by the Financial Services Authority (OJK) in 2015-2018 shows an increase in Islamic banking every year. In 2015 Sharia Commercial Banks (BUS) totaled 12 BUS; in 2016-2017, there were 13 BUS, and in 2018 there were 14 BUS as well as an increase in total assets of Islamic Commercial Banks by $10 \%$ and total assets of Islamic Business Units by $18 \%$. These improvements certainly show that there is a successful implementation of Islamic Sharia in muamalah.

Based on the 2010 population census data by the Central Statistics Agency (BPS), the majority of Indonesian people are Muslim, namely $87.21 \%$ or $207,176,162$ people (www.bps.go.id). Thus, the opportunity to develop Sharia banking in Indonesia is very good, as seen from the breadth of existing market segments. But the problem is that the Muslim population is not comparable to the growth of Islamic banks. Although the office network growth is relatively faster, the market share of Islamic banking in Indonesia is only $5.70 \%$ (www.ojk.go.id). This is evidence that there are still many Indonesian people who have not used Islamic banking services. 
Islamic Banking Students FEBI IAIN Purwokerto are students who have high knowledge about Islamic banks. Various subjects have been obtained by students useful to explore the knowledge of Islamic banking such as introduction to banking, banking law and nonbank financial institutions, classical muamalah contracts, contemporary muamalah contracts, and so on.

One of the objectives of Islamic banking studies is that students are expected to be able to apply the knowledge and expertise of Sharia banking management in the service of business and financial transaction activities in Islamic banking institutions in a professional manner (http://febi.iainpurwokerto.ac.id).

However, after conducting observations and interviews with several students, it was found that students have not been able to achieve these expectations. The average student still uses conventional banks as an intermediary for saving. It is ironic to see Islamic banking students who have a good understanding background on Islamic banks but are more interested in conventional banks.

Based on preliminary observations on 11-15 February 2019, researchers did not find any Islamic banks or conventional banks in the IAIN Purwokerto campus. The nearest Sharia bank branch office is $1.7 \mathrm{~km}$ from the campus, while the conventional bank branch office is $1.5 \mathrm{~km}$ from the campus. Researchers only found ATM facilities in front of the entrance gate of IAIN Purwokerto. This shows that the facilities provided by Islamic banks are still not optimal. The distance between the bank and the campus is too far so that students are less interested in saving at Islamic banks.

Also, researchers also obtained data that around 59\% of the 30 students interviewed had conventional bank accounts, and others had Sharia bank accounts. This is evidence that there are still many students who use conventional banks compared to Islamic banks as intermediaries to save them. As for the reasons given by students when interviewing is the lack of socialization conducted by Islamic banks and ATM facilities of Islamic banks, 
which are difficult to find, also triggers students to be less interested in using Islamic banking services.

There is little interest for students to save money in Islamic Banks, it is important for Islamic bank management to know the factors that can influence the community towards saving decisions in Islamic Banks. According to Soekidjo Notoatmodjo in Syahriyal (2018), knowledge or cognitive is a very important domain for the formation of one's actions (overt behavior). The results of research by Ergun \& Djedovic (2010) and Noor \& Sanrego (2011) state that knowledge has a positive and significant effect on savings decisions at Islamic Banks. However, this research contradicts the results of research conducted by Lestari (2015), which states that the knowledge variable can explain variations of $43,602 \%$ or being the smallest of all the variables studied, or it can be said that knowledge does not affect saving preferences.

Knowledge of Islamic banks as a factor that can influence savings decisions at Islamic Banks is promotion. The results of previous research conducted by Maisya (2013), Hapsari \& Beik (2014), and Istiqomah (2015) stated that promotion had a positive and significant effect on savings decisions in Islamic Banks. Whereas in the research of Yulianto, Yuniarto, \& Surachman (2010) and Arifin \& Khotimah (2014), which stated that promotion had no effect on savings decisions at Islamic Banks.

Another factor that can influence a person's decision to save at a Sharia Bank is a facility. The results of research conducted by Yupitri \& Sari (2012) and Viranti \& Ginanjar (2015) state that the facility has a positive and significant effect on savings decisions at Islamic Banks. Whereas in research Noor \& Sanrego (2011) and Junaidi (2015) stated that the facility does not affect the decision to save at a Sharia Bank.

According to Ajzen (2005), that the Theory of Planned Behavior (TPB) is an attitude model that estimates the interest or intention of consumers to carry out a behavior or action. The theory is also reinforced by the opinion of Jogiyanto (2008), which states that intention is defined as the desire to conduct behavior, where interest is not yet a behavior. Then the previous research 
conducted by Syahriyal (2018) showed that the saving interest variable as an intervening variable can increase the influence of perception and knowledge variables on saving decisions in Islamic Banks.

This study is a modification of a study conducted by Viranti \& Ginanjar (2015) on the Influence of Facilities, Promotion, Product, and Location of Islamic Banking on Decision of Non-Muslim Customers Patronizing at BRIS Case Study in BRI Syariah. The difference of this research with the previous research lies in the addition of the independent variable, which is the Islamic bank knowledge variable and the intervening variable, which is the saving interest variable. The subjects in this study were Islamic Banking Students FEBI IAIN Purwokerto for the Year of 2016/2017.

The purpose of this study are: 1) Analyze the positive and significant influence of the knowledge of Islamic banks on savings decisions in Islamic Banks, 2) Analyze the positive and significant influence of promotions on saving decisions in Islamic Banks, 3) Analyze the existence of positive and significant influences facilities for the decision to save at Islamic Banks, 4) Analyze the existence of a positive and significant influence of interest in saving on the decision to save at a Syariah Bank, 5) Analyze the existence of a positive and significant influence of knowledge of Islamic banks on saving interest, 6) Analyze the existence of a positive influence and significant promotion of saving interest, 7) Analyzing the positive and significant influence of facilities on saving interest, 8) Analyzing the positive and significant influence of Sharia bank knowledge on saving decisions in Islamic Banks through saving interest, 9) Analyzing the existence of positive influence, and significant promotion limited the decision to save at a Syariah Bank through saving interest, 10) Analyzing the positive and significant influence of the facility on saving decisions at a Syariah Bank through saving interest. 


\section{Literature review}

Theory of Planned Behavior (TPB) is a further development of the Theory of Reasoned Action (TRA). TRA explains that a person's interest in behavior is

JIEMB | 6 formed by two main factors, namely attitude toward the behavior and subjective norms, while in TPB, one more factor is added, which is Perceived Behavioral Control (PBC). According to Ajzen (2005) states that PBC is a perception of the level of difficulty of behavior to be implemented that comes from control beliefs.

Theory of Planned Behavior (TPB) is a model that can be used to assess a person's behavior. This theory has been recognized as the best model for understanding behavior change and has been proven to be appropriate for assessing savings decisions in Islamic banks. Therefore models like Theory of Planned Behavior (TPB) initiated by Ajzen (2005) are also used to explore planned behavior. Saving as a planned behavior is related to one's interests.

Background factors are factors that are present in a person. In this category, Ajzen (2005) includes three background factors, namely personal, social, and information. Personal factors are a person's general attitude toward something, personality traits, emotions, intelligence, and experience. Social factors include education, age, gender, income, religion, ethnicity. Information factors are knowledge, media, and intervention.

The knowledge of Islamic banks is related to the information factor, which is knowledge and influences control beliefs. Control beliefs are related to the belief that behavior or work that can be done. For example, with the knowledge they have about Islamic banks such as understanding, principles, products, and so on, students can consider the decision to save at Islamic Banks.

Promotion is an attempt to notify or offer a product or service to attract prospective customers. Promotion is also related to information. Namely, various promotional media carried out can influence one's actions, for example, through advertising on social media such as Facebook, Instagram, 
websites, and so on. If the promotion carried out by the Islamic bank is good, it can increase the decision to save at the Islamic Bank.

Facilities are also a background factor that can influence students' decisions to save at a Sharia Bank. The easier, faster, better organized and follows the development of technology, the more pampering customers can make them feel comfortable (Yupitri \& Sari, 2012). For example, Islamic banks provide clean office space facilities, comfortable waiting rooms, ATMs that are easy to find, and so on. If the facilities provided by Islamic banks are good, they can increase savings decisions at Islamic Banks.

Soekidjo Notoatmodjo (2003) in Syahriyal (2018) states that knowledge or cognitive is a very important domain for the formation of one's actions. This opinion is in line with the Theory of Planned Behavior (TPB) by Ajzen (2005), which states that knowledge is one of the background factors that can influence one's behavior or actions.

The results of the study by Ergun \& Djedovic (2010) stated that there is a positive and significant influence between knowledge of the decisions of the people of Bosnia and Herzegovina in choosing an Islamic bank. This research is strengthened by research conducted by Moor \& Sanrego (2011), which states that knowledge has a positive effect on people's preferences in choosing and saving in Islamic banking in DKI Jakarta.

In line with this research, Abhimantra, Rahmi Maulina, \& Agustianingsih (2013) also stated that knowledge influences the decision to save at a Sharia Bank. The higher the knowledge possessed, the higher the decision to save at the Islamic Bank. Conversely, if the knowledge of Islamic banks is low, the decision to save in Islamic banks will decrease. Based on the explanation that has been described, the hypothesis in this study is as follows:

H1: Knowledge of Islamic banks has a positive and significant effect on the decision to save at Bank Syariah

According to the Theory of Planned Behavior (TPB) by Ajzen (2005), promotion is included in the background factors that can influence one's actions or behavior. The results of previous research conducted by Maisya 
(2013) stated that advertising, sales promotion and public relations affect the decision to save at PT. Bank Negara Indonesia, Tbk. Bukittinggi Branch. This is in line with research by Hapsari \& Beik (2014), which states that promotion has JIEMB | 8 positive parameters on the decision of non-Muslims to use the services of Islamic banks.

In line with the research conducted by Yupitri \& Sari (2012), Istiqomah (2015), Viranti \& Ginanjar (2015) states that promotion has a positive effect on savings decisions at Islamic Banks. The better the promotion carried out by Islamic banks, increasing the decision to save at Islamic Banks also increases. Conversely, if the promotion of a Sharia bank is low, the decision to save at a Sharia bank will decrease. Based on the explanation that has been described, the hypothesis in this study is as follows:

H2: Promotion has a positive and significant effect on savings decisions in Islamic Banks

Facilities, according to the Theory of Planned Behavior (TPB) by Ajzen (2005), is one of the background factors that can influence behavior or actions. Yupitri \& Sari (2012), in her research, stated that the facility has a positive and significant effect on savings decisions at Islamic Banks. The research was also strengthened by Viranti \& Ginanjar's (2015) research, which stated that facilities, promotions, products, and locations greatly influenced the decision of non-Muslim customers to become BRI Syariah customers.

In line with the research conducted by Nadarajan, Selvanathan, \& Zamri (2018) stated that the facilities affect the selection of Islamic banks in Malaysia. The better the facilities provided by Islamic banks, the decision to save at Islamic Banks will increase. Conversely, if the facilities provided by a Sharia bank are bad, then the decision to save at a Sharia bank will decrease. Based on the explanation that has been described, the hypothesis in this study is as follows:

H3: Facilities have a positive and significant effect on the decision to save at Islamic Banks 
The intention in the Theory of Planned Behavior, according to Ajzen (2005), is a factor that can influence subsequent actions. Jogiyanto (2008) which states that interest intention is defined as the desire to conduct behavior, where interest is not yet a behavior.

The results of research conducted by Yulianti (2015) stated that the interests of the people of Aceh influence the decision to choose Sharia banking products in the city of Banda Aceh. Jogiyanto (2008) states that intention is defined as a desire to conduct behavior, where interest is not yet a behavior. If the interest in saving someone is high, then the decision to save at a Syariah Bank will increase. Conversely, if a person's interest in saving is low, then the decision to save at a Sharia Bank decreases. Based on the explanation that has been described, the hypothesis in this study is as follows:

H4: Interest in saving has a positive and significant effect on savings decisions at Islamic Banks

Knowledge is all information that can be obtained from various sources (books, newspapers, social media, etc.) that can influence one's actions and intentions. The results of research by Kristiyadi \& Hartiyah (2016) state that knowledge has a positive influence on saving interest in Islamic Financial Services Cooperatives (Case Study on BMT TAMZIS Wonosobo).

In line with the research of Wahyuni, Arifin, \& Sakur (2013), which states that the positive influence between knowledge and interest in using Islamic banking products. And research conducted by Wahyuni (2012) states that knowledge has a strong influence on interest in using Islamic banks. The higher the knowledge possessed, the greater the interest in saving at a Sharia Bank. Conversely, if the knowledge possessed is low then the interest in saving at Islamic banks also decreases. Based on the explanation that has been described, the hypothesis in this study is as follows:

H5: Knowledge of Islamic banks has a positive and significant effect on saving interest in Islamic Banks

Promotion is an activity to introduce a product so that the product can be sold to the public. The results of research by Firman (2018) which states that 
promotion influences the interest in saving people in Islamic banks. The research is also in line with Rahmanto's (2016) research, which states that promotion has a positive influence on saving interest in Islamic banks. The better the promotion carried out by Islamic banks, the more the interest in saving at Islamic Banks also increases. Conversely, if the promotion is low, then the interest in saving at Islamic banks also decreases. Based on the explanation that has been described, the hypothesis in this study is as follows:

H6: Promotion has a positive and significant effect on saving interest in Islamic banks

According to Lupiyoadi \& Hamdani (2009) states that the facility is the appearance, the ability of infrastructure, and the state of the surrounding environment in showing its existence to the external, which includes physical facilities, equipment, and equipment. The results of research conducted by Faisal (2014) stated that the facility has a significant effect on students' interest to become customers in Islamic banking.

The facilities contained in Islamic banking can help transaction activities for students and make students interested in becoming part of Islamic banking customers. The better and easier the facilities provided, the increasing interest in saving at a Sharia Bank. Conversely, if the facilities provided are poor or inadequate, then the interest in saving at a Sharia Bank also decreases. Based on the explanation that has been described, the hypothesis in this study is as follows:

H7: Facilities have a positive and significant effect on saving interest in Islamic Banks

According to the Theory of Planned Behavior by Ajzen (2005) which states that knowledge is one of the background factors that can influence a person's behavior or actions. The results of previous research conducted by Syahriyal (2018) stated that the intention to save as an intervening variable could strengthen the relationship between knowledge and the decision to save at a Sharia Bank. The higher the knowledge of Islamic banks and savings deposits that are owned, it can increase savings decisions at Islamic Banks. Conversely, 
if the knowledge of Islamic banks and one's intention to save is low, it can reduce savings decisions in Islamic Banks. Based on the explanation that has been described, the hypothesis in this study is as follows:

H8: Knowledge of Islamic banks has a positive and significant effect on the decision to save at a Syariah Bank through saving interest

Promotion is an activity to introduce a product so that the product is sold to the public. In the Theory of Planned Behavior by Ajzen (2005), promotion is included in the background factors that can influence a person's actions or behavior. Kotler \& Keller (2009) states that sales promotions, as a key element in marketing campaigns, are various sets of incentives that are mostly shortterm, designed to stimulate the purchase of certain products or services more quickly and more by consumers or traders.

If the promotion carried out by Islamic banks is intense and accompanied by a high interest in saving, it can increase savings decisions in Islamic Banks. Conversely, if the promotion of Islamic banks is not good and accompanied by a low interest in saving, it can reduce savings decisions in Islamic Banks. Based on the explanation that has been described, the hypothesis in this study is as follows:

H9: Promotion has a positive and significant effect on savings decisions in Islamic Banks through saving interest

Facilities, according to the Theory of Planned Behavior by Ajzen (2005), is one of the background factors that can influence subsequent behavior or actions. Lupiyoadi \& Hamdani (2009) states that the facility is the appearance, the ability of infrastructure, and the state of the surrounding environment in showing its existence to the external, which includes physical facilities, equipment, and equipment. Including facilities can be in the form of tools, objects, equipment, money, and working space.

The better and easier the facilities provided by Islamic banks if accompanied by a high interest in saving can increase savings decisions in Islamic Banks. Conversely, if the facilities provided by a Sharia bank are poor if accompanied by low intention to save, it can reduce the decision to save at a 
Oriesta Dhea Budi Utamy \& Ratieh Widhiastuti

Sharia bank. Based on the explanation that has been described, the hypothesis in this study is as follows:

H10: Facilities have a positive and significant effect on savings decisions in Islamic Banks through saving the intention

\section{Research methods}

This type of research is quantitative research. The population studied was all Islamic banking students of FEBI IAIN Purwokerto in the 2016/2017 class year totaling 106 students. The sampling technique in this study is to use the saturation sampling technique. The dependent variable in this study is the decision to save at Islamic Banks. The independent variables in this study are Sharia bank knowledge, promotions, and facilities. The intervening variable in this study is saving intention.

Savings decision variables in Islamic Banks use indicators developed by Setiadi (2005), namely 1) Stability in Islamic banking services, 2) Recommendations of others, 3) Seeking additional information, 4) Having cooperation with other banks in ATM matters. Variable knowledge of Islamic banks is measured using indicators developed by Saraswati (2016), namely 1) Knowledge of Islamic banking, 2) Knowledge of product characteristics in Islamic banks, 3) Ease of access.

Promotion variables are measured using indicators developed by Kasmir (2007), namely 1) Advertising, 2) Sales promotion, 3) Publicity, 4) Personal selling. Facility variables are measured using indicators developed by Kotler $\&$ Keller (2009), namely 1) Clean office space, 2) Waiting room and comfortable seating, 3) Large and safe parking area, 4) ATM spread and ease of found, 5) E-channel makes transactions easier. The saving interest variable is measured using indicators developed by Lucas and Britt (2003) in Rachman, Ginting, \& Amir (2015), namely 1) Attention, 2) Interest, 3) Desire, (4) Belief.

Data collection methods in this study used a questionnaire. The method of data analysis uses descriptive analysis and inferential analysis. Before a path analysis is performed, a prerequisite test consisting of the normality test is 
used to determine whether the residual data is normally distributed or not, the linearity test used to determine whether the data is linear or not, the multicollinearity test used to find out whether in the regression model there is collinearity between the independent variables, and the heteroscedasticity test is used to determine whether there are dissimilarities in residual variants from one observation to another. The model in this study can be seen in Figure 1.

Based on Figure 1, this research consists of two structural equations in regression analysis:

$$
Y=\rho_{1} X_{1}+\rho_{2} X_{2}+\rho_{3} X_{3}+\rho_{4} X_{4}+e_{1}
$$

and

$$
X_{4}=\rho_{1} X_{1}+\rho_{2} X_{2}+\rho_{3} X_{3}+e_{2}
$$

Figure 1. Path analysis diagram

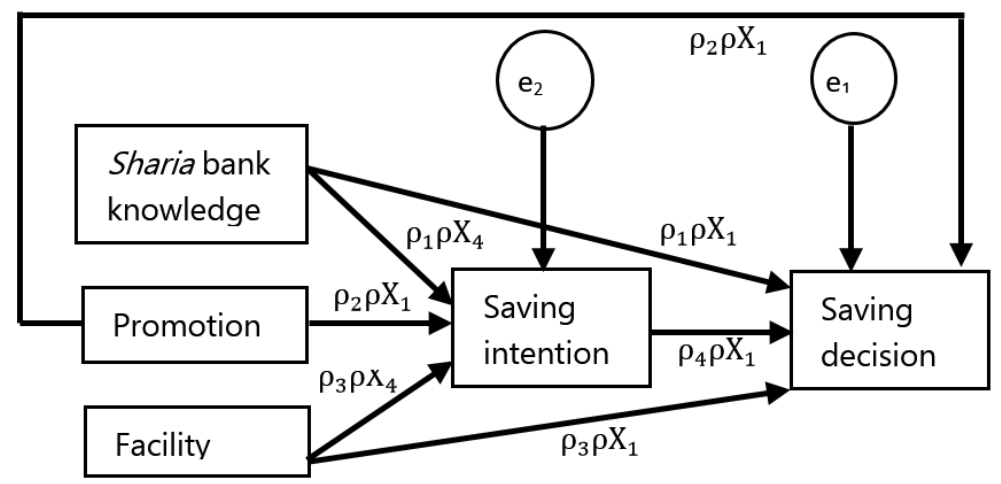

Table 1. Results of descriptive statistical analysis

\begin{tabular}{lll}
\hline Variable & Mean & Criteria \\
\hline The decision to save at Islamic Banks & 43,19 & High \\
Knowledge of Islamic banks & 44,63 & High \\
Promotion & 45,15 & Adequate \\
Facilities & 70,41 & Tinggi \\
Intention to save & 40,61 & Tinggi \\
\hline
\end{tabular}

\section{Results and discussion}


The first test was conducted to analyze the descriptive analysis of each variable in this study. The results of the descriptive statistical analysis of the variables in this study are presented in Table 1.

The results of a descriptive analysis of savings decisions in Islamic Banks show high criteria with the lowest value of 30 , the highest value of 60 , and an average value of 43.19 .

The results of the regression equation Table 2 obtained the second equation, $\mathrm{X} 4=0.239 \mathrm{X} 1+0.225 \mathrm{X} 2+0.471 \mathrm{X} 3+0.587$. Based on the second equation, shows the meaning that each increase in the knowledge variable of Islamic banks by one unit will cause an increase in interest in saving by 0,239 with the assumption of promotion and fixed facilities variables. Every promotion variable increases by one unit; it will cause an increase in interest in saving by 0.225 , assuming the variable knowledge of Islamic banks and fixed facilities. Each increase in the facility variable by one unit will cause an increase in interest in saving by 0.471 , assuming the variable knowledge of Islamic banks and permanent promotion. The variable residual knowledge of

Table 2. Multiple interest regression test results saving as dependent variable

\begin{tabular}{|c|c|c|c|c|c|}
\hline \multicolumn{6}{|c|}{ Coefficients $^{\mathrm{a}}$} \\
\hline \multirow[t]{2}{*}{ Model } & \multicolumn{2}{|c|}{ Unstandardized Coefficients } & \multirow{2}{*}{$\begin{array}{l}\text { Standardized Coefficients } \\
\text { Beta }\end{array}$} & \multirow[t]{2}{*}{$\mathrm{t}$} & \multirow[t]{2}{*}{ Sig. } \\
\hline & B & Std. Error & & & \\
\hline (Constant) & 3.417 & 2.913 & & 1.173 & .244 \\
\hline Knowledge & .254 & .091 & .239 & 2.785 & .006 \\
\hline 1 Promotion & .209 & .076 & .225 & 2.758 & .007 \\
\hline Facilities & .231 & .037 & .471 & 6.273 & .000 \\
\hline \multicolumn{6}{|c|}{ a. Dependent Variable: Intention to save } \\
\hline
\end{tabular}

Islamic banks, promotions, and facilities for interest in saving is 0.587 or $58.7 \%$. This means that saving interest is influenced by other variables not tested in this study by $58.7 \%$.

\section{Effect of knowledge of Islamic banks on savings decisions in Islamic banks}

Based on the results of the analysis of the t-test on the knowledge variables of Islamic banks, obtained an account of 3.043 with a significance of 
0.003. So $\mathrm{H} 1$ states that there is a positive and significant influence of the knowledge of Islamic banks to the decision to save in Islamic Banks in Islamic banking students FEBI IAIN Purwokerto in the year 2016/2017 is declared acceptable.

The results obtained from the descriptive analysis can be seen that the knowledge of Islamic banks is included in the high category. Various courses that have been taken can be a trigger for the high knowledge of Islamic banking students, such as the classical muamalah contract, contemporary muamalah contract, introduction to banking, banking law, and non-bank financial institutions, and others. The knowledge of Islamic banks in this study includes knowledge of Islamic banking, the characteristics of Islamic bank products, and knowledge about the ease of accessing Islamic banks.

The results of this study are by the Theory of Planned Behavior (TPB) by Ajzen (2005), which states that knowledge is one of the background factors that can influence one's behavior or actions. Islamic bank knowledge is included in the knowledge factor in the control belief category, where the category reinforces the explanation that behavior or work can be done with confidence. The theory is also reinforced by the opinion of Soekidjo Notoatmodjo (2003), stating that knowledge or cognitive is a very important domain for the formation of one's actions (overt behavior). Knowledge is more directed towards understanding, with a good understanding will be able to measure the magnitude of the benefits obtained, so that it will be easier in choosing and considering decisions (Kristiyadi \& Hartiyah, 2016).

The results of this study are also in line with research conducted by Ergun \& Djedovic (2010), which states that there is a positive and significant influence between the factors of knowledge on the decision of the people of Bosnia and Herzegovina in choosing an Islamic Bank. This research is strengthened by research conducted by Noor \& Sanrego (2011), which states that knowledge factors have a positive effect on people's preferences in choosing and saving in Islamic banking in DKI Jakarta. In line with this research, Abhimantra, Rahmi Maulina, \& Agustianingsih (2013) also stated that knowledge influences savings decisions in Islamic Banks. Based on the description above proves that 
Oriesta Dhea Budi Utamy \& Ratieh Widhiastuti

the knowledge of Islamic banks influences the decision to save in Islamic Banks. Thus, if the knowledge of Islamic banks is high will increase savings decisions in Islamic Banks.

\section{JIEMB | 16 Effect of promotion on savings decisions at Islamic banks}

Based on the results of the t-test analysis on the promotion variable, obtained t count of 2.317 with a significance of 0.022 . So $\mathrm{H} 2$ states that there is a positive and significant promotion effect on the decision to save at Islamic Banks in Islamic banking students FEBI IAIN Purwokerto in the year 2016/2017 is declared acceptable.

The research results obtained from the descriptive analysis can be seen that the promotion is included in the sufficient category. Promotion in this research includes advertising, sales promotion, publicity, and personal selling. Furthermore, the results of a descriptive analysis of savings decision variables in Islamic Banks are in the high category. This result can be interpreted that the decision to save Islamic banking students FEBI IAIN Purwokerto in the year $2016 / 2017$ is relatively high. With a good promotion, the decision of students to save at Islamic Banks will also increase.

The results of this study are by the Theory of Planned Behavior by Ajzen (2005), which states that promotion is included in the factor of information through the media that can influence one's actions or behavior. Kotler \& Keller (2009) states that sales promotions, as a key element in marketing campaigns, are various sets of incentives that are mostly short-term, designed to stimulate the purchase of certain products or services more quickly and more by consumers or traders. It is clear that communication with the wider community through public relations can affect the impression of a company or organization or the products or services offered.

The results of this study are in line with research conducted by Maisya (2013), which states that advertising, sales promotion, and public relations affect the decision to save at PT. Bank Negara Indonesia, Tbk. Bukittinggi Branch. This is in line with research by Hapsari \& Beik (2014), which states that the promotion variable has a positive parameter to the decision of non- 
Muslims to use the services of Islamic banks. In line with the research conducted by Yupitri \& Sari (2012), Istiqomah (2015), Viranti \& Ginanjar, 2015) which states that promotion has a positive effect on savings decisions at Islamic Banks. Based on the description above, it can be concluded that promotion by Islamic banks is very appropriate to attract prospective customers. Promotion carried out continuously will affect a person's decision to save at Islamic banks. The results showed a positive and significant effect, meaning that the more vigorous the promotion carried out, the decision to save in Islamic banks also increased.

\section{Effect of facilities on savings decisions at Islamic banks}

Based on the results of the t-test analysis on the facility, variables obtained $\mathrm{t}$ count of 2.208 with a significance of 0.029 . So $\mathrm{H} 3$ states that there is a positive and significant influence of the facility on the decision to save at a Sharia Bank in Islamic banking students FEBI IAIN Purwokerto in the year 2016/2017 is declared acceptable.

The results obtained from the descriptive analysis can be seen that the facilities are included in either category. The facilities provided by Islamic banks are good, according to Islamic banking students of FEBI IAIN Purwokerto in the year 2016/2017. Facilities in this study include clean office space, comfortable waiting and seating areas, spacious and safe parking spaces, ATMs that are spread out and easy to find, and e-channels make transactions easier.

The results of this study are by the Theory of Planned Behavior by Ajzen (2005), which states that facilities are included in the background factor, namely the media that can influence one's actions or behavior. This theory is reinforced by the opinion of Yupitri \& Sari (2012), which states that the easier, faster, better organized and follows the latest technological developments of a facility, the more pampering customers and create a sense of comfort for them.

The results of this study are in line with research conducted by Yupitri \& Sari (2012), which states that the facility has a positive and significant effect on 
savings decisions at Islamic Banks. The research was also strengthened by Viranti \& Ginanjar's (2015) research, which stated that facilities, promotions, products, and locations greatly influenced the decision of non-Muslim customers to become BRI Syariah customers. The better the facilities provided will improve the decision of non-Muslim customers to become BRI Syariah customers.

In line with the research conducted by Nadarajan, Selvanathan, \& Zamri (2018) stated that the facilities affect the selection of Islamic banks in Malaysia. Convenience is the most important criterion for the selection of Islamic banks in Malaysia, which generally includes convenient branch locations, access to branch locations, and availability of ATM services.

Based on the description above it can be concluded that the facilities provided by Islamic banks can attract prospective customers and influence the decisions was taken. The results showed a positive and significant effect, meaning that the better the facilities provided by Islamic banks, the decision to save at Islamic Banks would also increase.

\section{Effect of intention in savings decisions at Islamic banks}

Based on the results of the $t$-test analysis on saving interest variables obtained tcount of 6.175 with a significance of 0.000 . So that $\mathrm{H} 4$ states that there is a positive and significant effect on saving intention towards saving decisions at Islamic Banks in Islamic banking students, FEBI IAIN Purwokerto in the 2016/2017 class year is declared acceptable.

The results obtained from the descriptive analysis can be seen that saving interest is included in the high category. The interest of FEBI IAIN Purwokerto students in the 2016/2017 class year is high because the campus has a partnership with Islamic banks, namely BRI Syariah. And added a good background of religiosity supports student interest in Islamic banks.

The results of this study are by the Theory of Planned Behavior, as stated by Ajzen (2005), which states that human behavior is influenced by intention first. The theory is also reinforced by the opinion of Jogiyanto (2008), which 
states that intention is defined as the desire to conduct behavior, where interest is not yet a behavior.

The results of this study are also in line with research conducted by Yulianti (2015), which states that the interests of the people of Aceh have a positive and significant effect on the decision to choose sharia banking products in the city of Banda Aceh. This means, the higher the intention owned, the more customers will consider choosing Islamic bank products. Based on the description above, it can be concluded that the intention to save can influence saving decisions in Islamic banks. The results showed a positive and significant effect, meaning that the higher the intention to save someone, the decision to save in Islamic banks would also increase.

\section{The influence of Islamic bank knowledge on intention in Islamic banks}

Based on the results of the t-test analysis on the knowledge variables of Islamic banks, obtained t count of 2.785 with a significance of 0.006 . So H5 states that there is a positive and significant influence of the knowledge of Islamic banks to the interest in saving at Islamic Banks in Islamic banking students FEBI IAIN Purwokerto in the year 2016/2017 is declared acceptable.

The results obtained from the descriptive analysis can be seen that the knowledge of Islamic banks is included in the high category. Various courses that have been taken can be a trigger for the high knowledge of Islamic banking students, such as the classical muamalah contract, contemporary muamalah contract, introduction to banking, banking law, and non-bank financial institutions, and others. The knowledge of Islamic banks in this study includes knowledge of Islamic banking, the characteristics of Islamic bank products, and knowledge about the ease of accessing Islamic banks.

The results of this study are by the Theory of Planned Behavior (TPB) by Ajzen (2005), which states that knowledge is one of the background factors, the knowledge that can influence one's interest. The theory is strengthened by the opinion of Kristiyadi \& Hartiyah (2016), which states that high knowledge is one of the factors that are able to influence intention and has a positive and 
Oriesta Dhea Budi Utamy \& Ratieh Widhiastuti

significant influence on saving interest in Islamic Financial Services Cooperatives (Case Study on BMT TAMZIS Wonosobo).

The results of this study are also in line with research conducted by JIEMB | 20 Wahyuni, Arifin, \& Sakur (2013), which states that the positive influence between knowledge variables with interest in using Islamic banking products. As well as research conducted by Wahyuni (2012) states that knowledge has a strong influence on interest in using Islamic banks. Based on the description above, it can be concluded that knowledge about Islamic banks can influence interest in saving at Islamic Banks. The results showed a positive and significant effect, meaning that the higher the knowledge of Islamic banks owned, the more the interest in saving at Islamic Banks would also increase.

\section{Effect of promotion on saving intention in Islamic banks}

Based on the results of the t-test analysis on the promotion variable, obtained t count of 2.758 with a significance of 0.007 . So $\mathrm{H} 6$ states that there is a positive and significant promotion effect on saving intentions in Islamic Banks in Islamic banking students FEBI IAIN Purwokerto in the 2016/2017 class year is declared acceptable.

The research results obtained from the descriptive analysis can be seen that the promotion is included in the sufficient category. Promotion in this research includes advertising, sales promotion, publicity, and personal selling. Promotion conducted by Islamic banks is still not optimal, that is only with the socialization related to opening new accounts for new students.

The results of this study are by the Theory of Planned Behavior by Ajzen (2005), which states that promotion is one of the background factors through the media that can influence one's intention. By its nature that the purpose of promotion is to inform, persuade, and bind consumers. It is clear that communication with the wider community through promotion can affect the impression of a company or organization or the products or services offered.

The results of this study are also in line with research conducted by Firman (2018) and Rahmanto (2016), which states that promotional media influence 
the intention to save people in Islamic banks. Based on the description above, it can be concluded that the promotion can affect the intention to save at Islamic Banks. The results showed a positive and significant effect, meaning that the better the promotion carried out by Islamic banks, the intention to save at Islamic Banks will also increase.

\section{Effect of facilities on savings intention in Islamic banks}

Based on the results of the analysis of the t-test on saving interest variables obtained count of 6.273 with a significance of 0.000 . So $\mathrm{H} 7$ states that there is a positive and significant influence of the facility on saving interest in Sharia Banks in Islamic banking students FEBI IAIN Purwokerto in the year 2016/2017 is declared acceptable.

The results obtained from the descriptive analysis can be seen that the facilities are included in the good category. This shows that Islamic banks are already good at providing facilities for customers. Facilities in this study include clean office space, comfortable waiting and seating areas, spacious and safe parking spaces, ATMs that are spread out and easy to find, and e-channels make transactions easier.

The results of this study are by the Theory of Planned Behavior by Ajzen (2005), which states that facilities are one of the background factors, namely the media that can influence one's interest. This theory is reinforced by the opinion of Yupitri \& Sari (2012), which states that the easier, faster, well ordered, and follows the latest technological developments of a facility, the more pampering customers can create a sense of comfort for them.

In line with research conducted by Faisal (2014) which states that facilities have a significant effect on student interest in becoming customers in Islamic banking. The facilities contained in Islamic banking can help the transaction activities of students and make students interested in becoming part of Islamic banking customers.

Based on the description above, it can be concluded that the facilities can influence interest in saving money at Islamic Banks. The results showed a 
Oriesta Dhea Budi Utamy \& Ratieh Widhiastuti

positive and significant effect, meaning that the better the facilities carried out by Islamic banks, the more the interest in saving at Islamic Banks also increased.

Effect of knowledge of Islamic banks on savings decisions at Islamic banks through savings intention

Based on the results of the hypothesis test using the Sobel test obtained $t$ value of 2.4326 is greater than t table that is 1.6601 which means $\mathrm{H} 8$ which reads there is a positive and significant influence of knowledge of Islamic banks to the decision to save at Islamic Banks through interest in saving on Islamic banking students FEBI IAIN Purwokerto in the year of 2016/2017 is accepted. The results of calculations in the study that the direct effect of 0.214 or $21.4 \%$, while the indirect effect of 0.116 or $11.6 \%$ so that the total influence of knowledge of Islamic banks on savings decisions in Islamic Banks through saving intention of 0.33 or $33 \%$.

Based on the calculation results, it is known that the results of the indirect effect are smaller than the results of the direct influence but are still significant. The lower indirect effect shows a form of partial mediation, which means that in this study, the mediating variable, namely the interest in saving, can mediate the influence of the knowledge of Islamic banks to the decision to save at Islamic Banks, although not perfectly. That is because the knowledge of Islamic banks is considered important and influences the decision to save at Islamic Banks. Knowing Islamic banks obtained from a variety of taught subjects can improve savings decisions at Islamic Banks.

The results of this study are by the Theory of Planned Behavior by Ajzen (2005), which states that the interest in saving mediates between the variables of knowledge of Islamic banks to the decision to save at Islamic Banks. Knowledge of Islamic banks is one of the factors of information that is the knowledge that can affect a person's behavior.

High knowledge about Islamic banks will affect students' intention to save at Islamic Banks. If the intention to save at Islamic banks is high, then the decision to save at Islamic banks will also increase. The results of this study are 
also in line with research conducted by Syahriyal (2018), stating that the intention to save as an intervening variable can strengthen the relationship between knowledge and the decision to save at Islamic banks. It is saving at a Sharia Bank through an interest in saving at Islamic banking students FEBI IAIN Purwokerto. That is, if students know Islamic banks and high intention to save, it can increase savings decisions in Islamic Banks.

\section{Effect of promotion on savings decisions at Islamic banks through savings intention}

Based on the results of the hypothesis test using the Sobel test obtained $t$ count value of 2.6908 is greater than t table that is 1.6601 which means H9 which reads there is a positive and significant influence on the promotion of savings decisions in Islamic Banks through saving intention on Islamic banking students FEBI IAIN Purwokerto in the year of 2016/2017 is accepted. The results of calculations in the study that the direct effect of 0.115 or $11.5 \%$, while the indirect effect of 0.109 or $10.9 \%$ so that the total influence of the promotion of saving decisions in Islamic Banks through saving intention of 0.264 or $26.4 \%$.

Based on the calculation results, it is known that the results of the indirect effect are smaller than the results of the direct influence but are still significant. The lower indirect effect shows the form of partial mediation, which means that in this study, the mediating variable, namely saving intention, can mediate the influence of the knowledge of Islamic banks to the decision to save at Islamic Banks, although not perfectly. That is because the promotion proved to influence the decision to save at Islamic Banks. Promoting prospective customers in a variety of attractive ways, it can improve savings decisions at Islamic Banks.

The results of this study are by the Theory of Planned Behavior by Ajzen (2005), which states that before conducting a behavior, it must have an intention first. Before the intention, several background factors can influence a person in determining his decision. 
One of the factor is a promotion that is included in the information factor through the media; various promotions have been carried out by Islamic banks to attract the attention of Islamic banking students FEBI IAIN Purwokerto. One way is to offer to open an Islamic bank account, in this case, a BRI Syariah account. In this way, students are expected to be interested in the products offered so that they choose Islamic banks as intermediaries to save.

Based on the description above, it can be concluded that the promotion has a positive and significant effect on the decision to save at a Syariah Bank through the intention to save on FEBI IAIN Purwokerto Islamic banking students. That is, if the promotion carried out by Islamic banks is good and is accompanied by high intention to save, it can increase savings decisions at Islamic Banks.

\section{Effect of facilities on savings decisions at Islamic banks through savings intention}

Based on the results of the hypothesis test using the Sobel test obtained $t$ value of 4.3559 is greater than $t$ table that is 1.6601 which means $\mathrm{H} 10$ which reads there is a positive and significant influence of facilities on the decision to save at Islamic Banks through saving intention in Islamic banking students FEBI IAIN Purwokerto in the year of 2016/2017 is accepted. The results of calculations in the study that the direct effect of 0.115 or $11.5 \%$, while the indirect effect of 0.228 or $22.8 \%$ so that the total effect of the facility on saving decisions in Islamic Banks through saving intention is 0.383 or $38.3 \%$.

Based on the results of calculations, it is known that the results of indirect effects are greater than the results of direct effects but are still significant. The higher indirect effect shows the form of partial mediation, which means that in this study, the mediating variable, namely saving intention, can mediate the influence of the knowledge of Islamic banks on savings decisions in Islamic Banks. That is because the facility is proven to influence the decision to save at a Sharia Bank. Providing good facilities for the convenience of customers, it can improve savings decisions at Islamic Banks. 
The results of this study are by the Theory of Planned Behavior by Ajzen (2005), which states that the interest in saving can be an intermediary between the facility and the decision to save at an Islamic Bank. The facility is a background factor, which is the media that can determine the next action or behavior, in this case, the decision to save at a Sharia Bank.

Interest is included in the intention factor that can bridge the background factors with behavior. The easier, faster, better organized, and follows the latest technological developments of a facility, the more pampering customers will be to make them feel comfortable (Yupitri \& Sari, 2012).

Based on the description above, it can be concluded that the facility has a positive and significant effect on decision saving at a Sharia Bank through intention in saving at Islamic banking students FEBI IAIN Purwokerto. That is if the facilities provided by a good Islamic bank and accompanied by a high intention to save can increase savings decisions at Islamic Banks.

\section{Conclusion}

Based on the results of research and discussion concluded that (1) there is a positive and significant influence of knowledge of Islamic banks, promotions, facilities, and intention to save on savings decisions in Islamic Banks, (2) there is a positive and significant influence of knowledge of Islamic banks, promotions, and facilities to saving intention in a Sharia Bank, (3) there is a positive and significant influence of knowledge of a Sharia bank, promotion, and facilities on the decision to save at a Sharia Bank through an intention to save, (4) the variable saving interest has the most dominant influence on a decision to save at a Sharia Bank.

The limitation in this study is that this study only took samples in FEBI IAIN Purwokerto's 2016/2017 Sharia banking students so that the results of the study may not be generalized, it is suggested that further research can expand the sample used. Also, the suggestion from this research is that Islamic banks are expected to be able to improve the available facilities and increase promotions so that prospective customers can find out what products are offered so that the intention and decision to save at Islamic Banks can increase. 
Oriesta Dhea Budi Utamy \& Ratieh Widhiastuti

\section{References}

Abhimantra, A., Rahmi Maulina, A., \& Agustianingsih, E. (2013). Analisis FaktorFaktor Yang Mempengaruhi Nasabah (Mahasiswa) Dalam Memilih Menabung pada Bank Syariah. Proceeding PESAT, 5(10), 5-12. https://doi.org/10.13140/RG.2.2.30630.32324

Ajzen, I. (2005). Attitudes, Personality and Behavior. New York: Open University Press-Mc Graw- Hill Education.

Arifin, A., \& Khotimah, H. (2014). Pengaruh Produk, Pelayanan, Promosi dan Lokasi Terhadap Keputusan Masyarakat Memilih Bank Syariah di Surakarta. Jurnal FEB UMS, 163-184.

BPS. (2010). Sensus Penduduk Tahun 2010. Retrieved from www.bps.go.id

Dita Pertiwi, \& Ritonga, H. D. H. (2010). Analisis Minat Menabung Masyarakat Pada Bank Muamalat di Kota Kisaran. Jurnal Ekonomi Dan Keuangan, 1(1), 61-69.

Ergun, U., \& Djedovic, I. (2010). Islamic Banking with a Closer Look at Bosnia and Herzegovina: Knowledge, Perceptions and Decisive Factors for Choosing Islamic Banking. 8th International Conference on Islamic Economics and Finance Islamic, 1-12.

Faisal. (2014). Faktor - Faktor yang Mempengaruhi Minat Mahasiswa Untuk Menjadi Nasabah di Bank Syariah (Studi pada Mahasiswa Ekonomi dan Perbankan Islam UMY). Jurnal Administrasi, 13(1).

FEBI IAIN. (2018). Profil Jurusan Perbankan Syariah. Retrieved from www.febi.iain.purwokerto.ac.id

Firman, R. N. (2018). Pengaruh Media Promosi Perbankan Syariah Terhadap Minat Menabung Masyarakat di Bank Syariah Mandiri Pasuruan. Jurnal Studi Pendidikan Islam, 05, No.1.

Ghozali, I. (2013). Aplikasi Analisis Multivariate Dengan Program IBM SPSS 21. Semarang: Universitas Diponegoro.

Hapsari, F. T., \& Beik, I. S. (2014). Analisis Faktor-Faktor yang Mempengaruhi Nasabah Non Muslim dalam Menggunakan Jasa Bank Syariah di DKI Jakarta. Jurnal Al-Muzara'ah, 2(1),69-87. https://doi.org/10.29244/jam.2.1.75-94

Istiqomah, Y. N. A. (2015). The Influence of Marketing Mix (Product, Price, Place, and Promotion) and Service on Customer's Decision of Using 
BSM Saving Products. Global Review of Islamic Economics and Business, 3(2), 73-98.

Jogiyanto. (2008). Sistem Informasi Keperilakuan. Yogyakarta: C.V ANDI OFFSET.

Junaidi. (2015). Persepsi Masyarakat untuk Memilih dan Tidak Memilih Bank

Syariah (Studi Kota Palopo). Jurnal Fokus Bisnis, 14(02), 1-13.

Kasmir. (2007). Pemasaran Bank (1st ed.). Jakarta: Kencana.

Kotler, P. (2009). Manajamen Pemasaran. Indonesia: PT Macanan Jaya Cemerlang.

Kristiyadi, \& Hartiyah, S. (2016). Pengaruh Kelompok Acuan, Religiusitas, Promosi dan Pengetahuan Tentang Lembaga Keuangan Syariah Terhadap Minat Menabung di Koperasi Jasa Keuangan Syariah (Studi Kasus pada BMT TAMZIS Wonosobo). Jurnal Ekonomi Dan Teknik Informatika, 5(Hutabarat 2010), 44-63.

Lestari, A. M. (2015). Pengaruh Religiusitas, Produk Bank, Kepercayaan, Pengetahuan dan Pelayanan Terhadap Preferensi Menabung Pada Perbankan Syariah (Studi Kasus Pada Mahasiswa Fakultas Ekonomi dan Bisnis Universitas Brawijaya Malang). Jurnal Ilmiah Mahasiswa Fakultas Ekonomi Dan Bisnis Universitas Brawijaya, 3(1), 1-18.

Yupitri, E., \& Sari, raina linda. (2012). Analisis Faktor - Faktor yang Mempengaruhi Non Muslim Menjadi Nasabah Bank Syariah Mandiri di Medan. Jurnal Ekonomi Dan Keuangan, 1(Desember), 46-60. https://doi.org/10.1063/1.1854735 